Original Article

\title{
Seasonal analysis of food items and feeding habits of endangered riverine catfish Rita rita (Hamilton, 1822)
}

\author{
Análise sazonal de itens e hábitos alimentares de bagres ribeirinhos Rita rita \\ (Hamilton, 1822) ameaçados de extinção

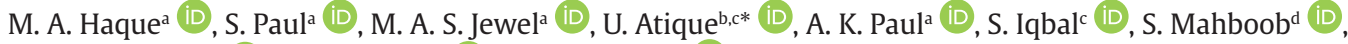 \\ K. A. Al-Ghanim ${ }^{d}$ (D), F. Al-Misned ${ }^{d}$ (iD) and Z. Ahmed ${ }^{d}$ (iD \\ aUniversity of Rajshahi, Faculty of Agriculture, Department of Fisheries, Rajshahi, Bangladesh \\ ${ }^{\mathrm{b} C}$ Chungnam National University, Department of Bioscience and Biotechnology, Chungnam, South Korea \\ 'University of Veterinary and Animal Sciences, Department of Fisheries and Aquaculture, Lahore, Pakistan \\ dKing Saud University, College of Science, Department of Zoology, Riyadh, Saudi Arabia
}

\begin{abstract}
This investigation presents the food and feeding activity of and endangered riverine catfish Rita rita, during February 2017-January 2018. A total of 225 fish individuals was analyzed for stomach contents by characterizing the dominant food items and morphometric features. The results divulged ten major food items consumed, preferably fish scales and eggs, teleost fishes, copepods, cladocerans, rotifers, and mollusks. Total length and body weight of fish varied between $9-34 \mathrm{~cm}(20.53 \pm 6.90 \mathrm{~cm})$ and $10-400 \mathrm{~g}(9125.94 \pm 102.07 \mathrm{~g})$, respectively. The index of relative importance (IRI\%) showed the importance of rotifers over the other food items. Morisita's index of diet overlap indicated seasonal variations in catfish diets with summer and monsoon displaying the least overlap, while maximum overlap during monsoon and winter seasons. The non-metric multidimensional scaling (nMDS) indicated the close association between the food items available during summer and winter seasons with a significant difference among the seasons (ANOSIM, $R=0.638, P=0.013$ ). Levin's niche breadth index arranged in the order of $0.88>0.81>0.78>0.63>0.43$ for the size classes of V, IV, III, II and I, respectively. The PCA explained $95.39 \%$ of the total variance among the food items and fish size groups. Small-sized fish individuals displayed a greater correlation with food items suitable for their mouth size. In conclusion, the variety and frequency of food items recorded indicated considerable feeding plasticity and opportunistic feeding behavior with a shift from carnivorous to omnivorous feeding nature. This study could render useful information on the food and feeding habits of $R$. rita and provide background for preparing its diet for future aquaculture practices.
\end{abstract}

Keywords: Rita rita, feeding habits, stomach contents, plasticity, multivariate analysis, morphometric.

\begin{abstract}
Resumo
Esta investigação apresenta a alimentação e a atividade alimentar de bagres ribeirinhos Rita rita ameaçados de extinção, no período de fevereiro de 2017 a janeiro de 2018. Um total de 225 peixes foi analisado quanto ao conteúdo do estômago, caracterizando os itens alimentares dominantes e as características morfométricas. Os resultados apresentaram dez principais itens alimentares consumidos, preferencialmente escamas e ovos de peixes, teleósteos, copépodes, cladóceros, rotíferos e moluscos. O comprimento total e o peso corporal dos peixes variaram entre 9-34 cm (20,53 $\pm 6,90 \mathrm{~cm})$ e 10-400 g (9125,94 $\pm 102,07 \mathrm{~g})$, respectivamente. O índice de importância relativa (IRI\%) mostrou a importância dos rotíferos sobre os demais itens alimentares. O índice de sobreposição de dieta de Morisita indicou variações sazonais nas dietas de bagres no verão e nas monções, exibindo a menor sobreposição, enquanto a sobreposição máxima ocorreu durante as estações das monções e do inverno. A escala multidimensional não métrica (nMDS) indicou a estreita associação entre os itens alimentares disponíveis durante o verão e o inverno, com uma diferença significativa entre as estações (ANOSIM, $\mathrm{R}=0,638, \mathrm{P}=0,013$ ). $\mathrm{O}$ índice de amplitude de nicho de Levin foi organizado na ordem de $0,88>0,81>0,78>0,63>0,43$ para as classes de tamanho de V, IV, III, II e I, respectivamente. O PCA explicou 95,39\% da variação total entre os itens alimentares e os grupos de tamanho de peixes. Peixes de pequeno porte apresentaram maior correlação com itens alimentares adequados ao tamanho da boca. Em conclusão, a variedade e a frequência dos itens alimentares registrados indicaram plasticidade alimentar considerável e comportamento alimentar oportunista, com uma mudança da natureza carnívora para onívora. Este estudo pode fornecer informações úteis sobre os hábitos alimentares e de alimentação de R. rita e apresentar subsídios para a preparação de sua dieta em futuras práticas de aquicultura.
\end{abstract}

Palavras-chave: Rita rita, hábitos alimentares, conteúdo estomacal, plasticidade, análise multivariada, morfométrico.

*e-mail: physioatique@gmail.com; shahidmahboob60@hotmail.com

Received: April 23, 2020 - Accepted: June 26, 2020

This is an Open Access article distributed under the terms of the Creative Commons Attribution License, which permits unrestricted use, distribution, and reproduction in any medium, provided the original work is properly cited. 


\section{Introduction}

Investigations on feeding habits and preferences provide essential data on the trophic interactions and nutrient flow in the aquatic ecosystems (Fatema et al., 2013; Campos et al., 2015; Atique and An, 2018, Atique et al., 2019; Saeed et al., 2020; Rahman et al., 2020) as the success of a fish species in its typical habitat is associated with its diet because it provides crucial insights into its natural history (Braga et al., 2012; Batool et al., 2018; Kim et al., 2019; Iqbal et al., 2017a, 2020; Khanom et al., 2020). The management decisions on the management of fish populations include numerous aspects of fish biology, feeding preferences, and water quality management (Atique and An, 2020; Atique et al., 2020a, b; Hara et al., 2020; Jewel et al., 2020; Momi et al., 2021). Therefore, investigations on the trophic ecology, mainly targeting the food and feeding preferences of valuable fish species, are incredibly vital for the conservation and restoration of endangered fish species and their stocks (Blaber, 1997; Fagbenro et al., 2000; Bae et al., 2020; Moon et al., 2020). Changes in dietary preferences of a fish species largely depend on the availability of preferred prey items in the associated environment. An abundance of favorite prey items in the environment regulates their predominance of food items in the fish stomach (Palmeira and Monteiro-Neto, 2010; Gondal et al., 2020; Kim et al., 2021). Moreover, energy requirements by fish in a specific phase of life sometimes induce ontogenetic shifts in dietary mode and selectivity (Cruz Escalona and Abitia Cárdenas, 2004). Thus, analysis of stomach contents based on the seasonal and morphological traits could help in establishing standard practices in fishery science and could provide relevant scientific advice on sustainable fisheries management (Hyslop, 1980; Zacharia, 2004).

Rita rita is a commercially exploited fish species in Bangladesh and is appreciated for its high nutritious value (Mohanty et al., 2015). The natural distribution of this fish species is described from shallow and muddy to clear waters in rivers and wetlands of Bangladesh (Islam et al., 2015; Galib et al., 2016; Sultana et al., 2017; Jewel et al., 2018; Parvez et al., 2019) and in the closer countries (Gupta, 2015; Iqbal et al., 2017b; Muhammad et al., 2019). Nowadays, the populations of $R$. rita in the riverine ecosystem of Bangladesh are facing the critical threat of extinction due to over-exploitation and loss of breeding grounds (Molla et al., 2008). Consequently, it has been categorized as endangered fish species in Bangladeshi waters (IUCN, 2010). Therefore, captive breeding could offer a suitable option to conserve this fish species. Several successful experiments of the induced breeding in $R$. rita have been performed in Bangladesh (Molla et al., 2008; Taslima and Mollah, 2012), and now the task at hand for the fisheries scientists is to improve the captive culture system of this species. However, the successful domestication of this endangered fish species could only be achieved by suitable rearing in an aquaculture system. Therefore, precise knowledge of the feeding biology and food preferences is essential to the development of viable and appropriate artificial feed for this species. To date, comprehensive research on the feeding habits of $R$. rita lacks in the Padma River, Bangladesh.
Considering the grander importance and imminent threats of extinction, this study was planned to investigate the indepth food and feeding habits of $R$. rita. We also performed the quantitative stomach content analysis with potential variations based on seasons and fish body size that are linked with feeding variations in $R$. rita.

\section{Materials and Methods}

\subsection{Study area}

The present study covers approximately $50 \mathrm{~km}$ upstream stretch of Padma River from Godagari (24 $27^{\prime} 34.79^{\prime \prime} \mathrm{N}$ and $\left.88^{\circ} 20^{\prime} 09.54^{\prime \prime} \mathrm{E}\right)$ to Charghat $\left(24^{\circ} 16^{\prime} 43.25^{\prime \prime} \mathrm{N}\right.$ and $88^{\circ} 45^{\prime} 06.75^{\prime \prime} \mathrm{E}$ ) points (Figure 1). This river characterized by the discharge of effluent from vegetable markets and slaughter discharges and from household septic tanks. Inundation of this river due to monsoon flood causes the recruitment of several food items from adjacent wetlands. Therefore, the presence of diversified food items in water makes this ideal river habitat for experimenting on food and feeding habit of Rita rita.

\subsection{Sample collection}

The fish samples were collected from the commercial catch of fishers during summer (February to April 2017), monsoon (July to September 2017), and winter (November 2017 to January 2018) seasons. A total of 225 pieces of $R$. rita were collected during the sampling period, with a sample size of 75 fish individuals in each sampling season. After procurement, the fish samples were stored in a $10 \%$ solution of alcohol and transported to the laboratory for further analyses. In the laboratory, morphometric records such as total length (TL), body weight (BW), stomach weight with food and without food contents, horizontal mouth gape (HG), and vertical mouth gape (VG) was measured to the nearest 0.01 unit ( $\mathrm{cm}$ and g, respectively). Measurement of HG and VG were further used to analyze the mouth area (MA) dimension according to the ellipse model of Erzini et al. (1997). The formula of the MA is as follows (Equation 1).

$$
(\mathrm{MA}=0.25 \pi(\mathrm{VG} \times \mathrm{HG}))
$$

where: MA is the ellipse area measured in $\mathrm{cm}^{2}$. Size related variations of food items were analyzed after grouping the collected samples into 5 size categories such as $\mathrm{I}=9-14$, II = >14-19, III = >19-24, IV = >24-29 and V = >29-34 cm.

After dissecting the stomach, the food contents of each fish were identified by visual and microscopic observations to the lowest possible taxonomic level. The identified food items were then counted and weighed in grams to the nearest 0.001 precision using a digital weighing machine.

\subsection{Estimation of food contents}

The importance of each food item in the stomach of $R$. rita was assessed by employing the index of relative 


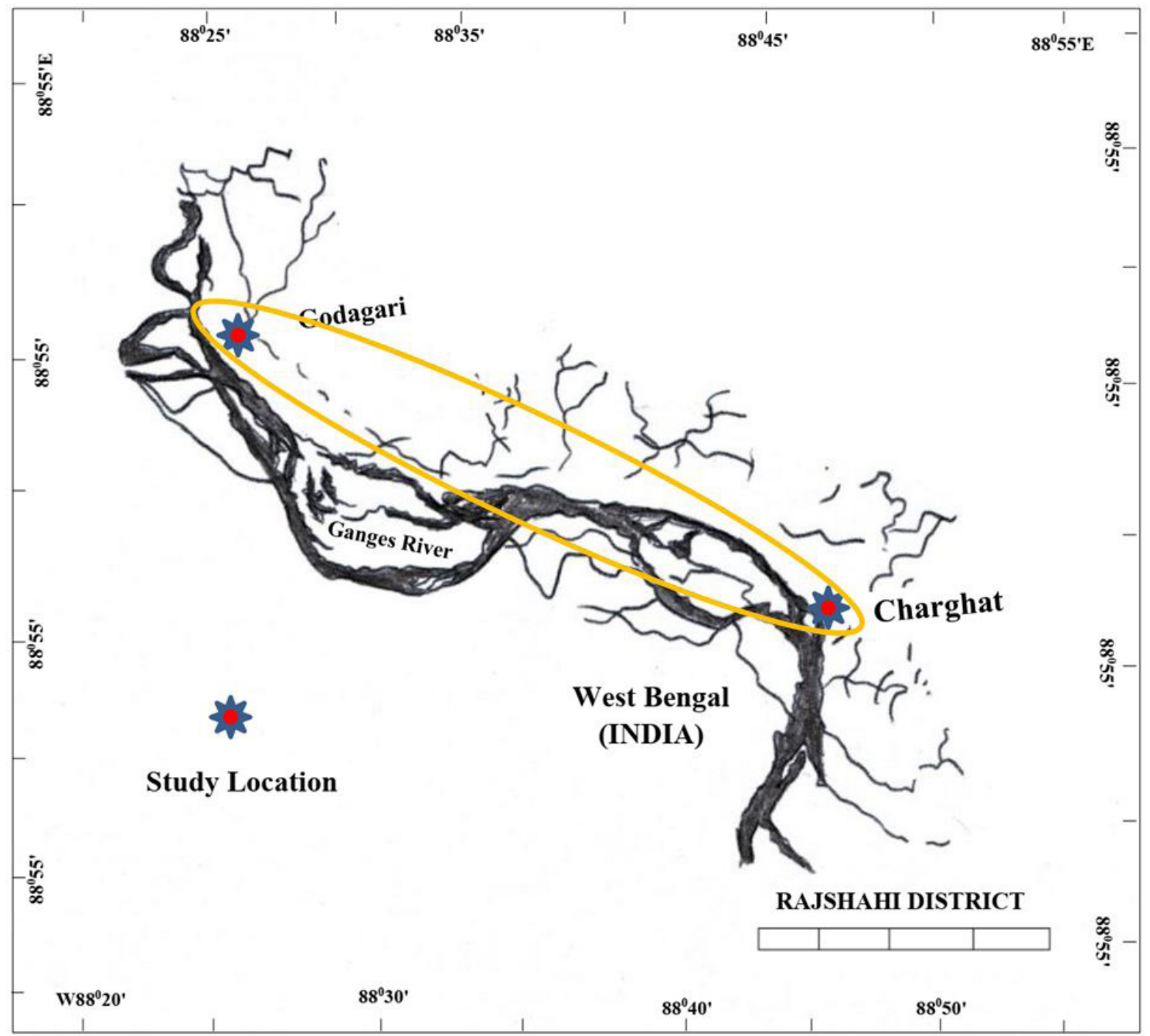

Figure 1. Study area map showing the stretch of Padma River covered during the sampling of $R$. rita.

importance (IRI), which was calculated according to the Formula 2 given by Ugwumba and Ugwumba (2007).

$$
\mathrm{IRI} \%=(\% \mathrm{~N}+\% \mathrm{~W}) * \% \mathrm{FO}
$$

where: \%FO, \% $\mathrm{N}$ and \%W are the frequency of occurrence, numerical composition, and the weight composition of each food item. The feeding activity of each fish individuals was measured by the degree of stomach fullness.

The stomachs were classified as full (100\%), threequarters filled (75\%), half-filled (50\%), one-quarter filled (25\%), and empty (0\%) according to Zahorcsak et al. (2000). Season and size-related dietary overlap and niche breadth of $R$. rita were analyzed by Morisita's index of similarity and Levin's standardized niche breadth index (Krebs, 1999a, b) using \%FO data of all food items. Morisita's index ranges from 0 (no overlap) to slightly greater than 1 (high overlap), and Levin's index is measured on a scale from 0 (minimum niche breadth) to 1 (maximum niche breadth).

\subsection{Seasonal variations and statistical analyses}

Seasonal variation in the food items of $R$. rita was assessed by non-metric multidimensional scaling (nMDS). To test significant difference in food items between the seasons, analysis of similarity (ANOSIM) was also performed using the Bray-Curtis similarity matrix. Furthermore, a similarity percentage analysis (SIMPER) was done with the objective of identifying the food items mostly responsible for the formation of seasonal groups. Principal component analysis (PCA) was applied to inspect the primary sources of diet variation among the size groups. The difference in the diet composition of $R$. rita was also compared by cluster analysis (CA) using the Bray-Curtis similarity index.

The length-weight relationship of $R$. rita was estimated using the following Equation 3.

$$
\mathrm{BW}=\mathrm{aTL}^{\mathrm{b}}
$$

where: BW is the body weight ( $\mathrm{g}), \mathrm{TL}$ is the total length $(\mathrm{cm}), a$ is the intercept and $b$ the slope. The relation between 
mouth size dimensions and total length was estimated using the following Equations 4, 5 and 6, respectively.

$$
\begin{aligned}
& (\mathrm{HG}, \mathrm{VG}, \mathrm{MA})=\mathrm{a}+\mathrm{b}(\mathrm{TL}) \\
& \mathrm{HG}=\mathrm{a}+\mathrm{b}(\mathrm{VG})
\end{aligned}
$$

$$
(\mathrm{HG}, \mathrm{VG})=\mathrm{a}+\mathrm{b}(\mathrm{MA})
$$

The coefficient of determination $\left(r^{2}\right)$ was used to analyze the interaction between the variables and the significance level of each estimation by one-way analysis of the variance (ANOVA). Finally, the relationship between the food items and the morphometric measures was investigated by canonical correspondence analysis (CCA). All the multivariate analyses were performed by using \% FO data after the transformation into corresponding square root data. All the multivariate analyses (nMDS, ANOSIM, SIMPER, PCA, CA and CCA) were done using PAST (v. 3) (Hammert et al., 2001) and univariate (ANOVA) using SPSS (v. 20).

\section{Results}

\subsection{Diet composition and feeding intensity}

The examination of stomach contents of 225 individuals of $R$. rita resulted in the identification of 10 major food items, including fish scales, fish eggs, teleost fishes, copepods, cladocerans, rotifers, insects, mollusks, plant materials, and mud and sand particles (Table 1). The index of relative importance (IRI\%) based analysis showed a variation among the seasons and size groups of fish. IRI\% value of fish scales and teleosts were found higher during the summer season as well as in the fish size group $>29-34 \mathrm{~cm}$. However, insects and mollusks displayed the higher IRI\% values during summer, and in the size group
$>24-29 \mathrm{~cm}$. Fish eggs, plant materials, and mud and sand particles were the most contributory food item in fish stomach contents during monsoon season based on the IRI\% index. These food items were mostly preferred by the fish size group $>29-34 \mathrm{~cm}$, except for mud and sand particles, for which the index value was higher in fish size group $>24-29 \mathrm{~cm}$. During the winter season, the IRI\% values of copepods, cladocerans, and rotifers were higher compared to other seasons, and these were the primary food items for the fish size groups of 9-14 and $>14-19 \mathrm{~cm}$. Overall, rotifers were the essential food item in the diet of $R$. rita in Padma River. The seasonal and size-related variations in the \% fullness of fish stomachs were also recorded during the study period and shown in Figure 2. A higher number of fish stomachs were witnessed to be empty (44\%) during the monsoon season, while the full bellies showed only $28 \%$ during the summer season. Fish with a larger size group ( $>29-34 \mathrm{~cm}$ ) was found with the highest percentage of empty (80\%) stomach, whereas $>19-24 \mathrm{~cm}$ size group fish individuals were found with the highest rate of full bellies.

\subsection{Seasonal variation in food items}

Morisita's index of diet overlap indicated variations in diets among the seasons, with summer and monsoon seasons showing the least food overlap (Morisita's index $=0.66$ ). However, the maximum diet overlap was displayed between monsoon and winter (Moisita's index $=0.74$ ) seasons, while moderate overlap was noticed between summer and winter (Morisita's index $=0.73$ ). The summer season was found to occupy the diverse niche breadth (Levin's index $=0.76$ ) followed by the winter season (Levin's index $=0.60$ ) with the narrowest during monsoon season (Levin's index $=0.58$ ). The analysis using non-metric multidimensional scaling (nMDS) indicated the close association between the food items available during summer and winter seasons. In contrast, the distinction of monsoon samples was evident from the past two sampling seasons (Figure 3). However, there was an overlap between the dietary food items during winter and monsoon seasons.

\begin{tabular}{|c|c|c|c|c|c|c|c|c|c|}
\hline \multirow{2}{*}{ Stomach contents } & \multicolumn{3}{|c|}{ Seasons } & \multicolumn{6}{|c|}{ Fish size groups } \\
\hline & Summer & Monsoon & Winter & 9-14 & $>14-19$ & $>19-24$ & $>24-29$ & $>29-34$ & Overall \\
\hline Fish scale & 2.58 & 0.00 & 0.49 & 0.00 & 0.81 & 0.70 & 1.85 & 4.27 & 1.02 \\
\hline Fish eggs & 0.00 & 6.15 & 0.00 & 0.10 & 0.12 & 0.29 & 0.77 & 2.73 & 2.05 \\
\hline Teleost & 6.69 & 0.01 & 0.10 & 0.00 & 0.18 & 4.66 & 4.40 & 7.56 & 2.27 \\
\hline Copepods & 17.45 & 23.11 & 23.82 & 24.67 & 23.41 & 23.59 & 17.10 & 20.52 & 21.46 \\
\hline Cladocerans & 22.61 & 24.57 & 25.59 & 25.26 & 25.46 & 24.32 & 24.12 & 21.85 & 24.25 \\
\hline Rotifers & 25.32 & 26.86 & 33.09 & 30.78 & 32.63 & 26.63 & 26.44 & 23.18 & 28.42 \\
\hline Insects & 10.86 & 2.79 & 4.54 & 3.82 & 4.72 & 6.46 & 10.13 & 7.30 & 6.06 \\
\hline Mollusks & 3.37 & 0.00 & 0.02 & 0.00 & 0.05 & 1.03 & 2.76 & 2.07 & 1.13 \\
\hline Plant materials & 0.00 & 0.46 & 0.01 & 0.00 & 0.03 & 0.09 & 0.03 & 0.53 & 0.15 \\
\hline Mud and sand particles & 11.16 & 16.05 & 12.35 & 15.36 & 12.58 & 12.23 & 12.39 & 9.99 & 13.19 \\
\hline
\end{tabular}

Table 1. Index of relative importance (IRI\%) calculations based on stomach contents (food items) in different seasons and size groups in $R$. rita sampled from Padma River. 


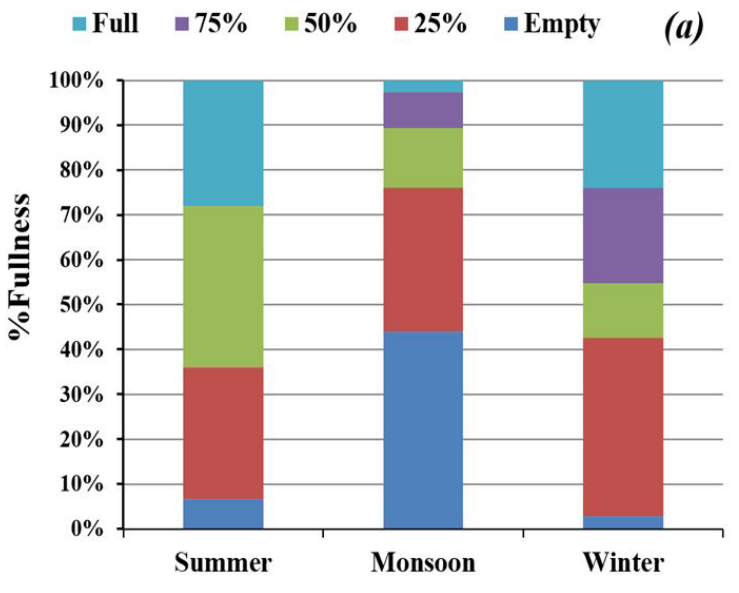

Seasons

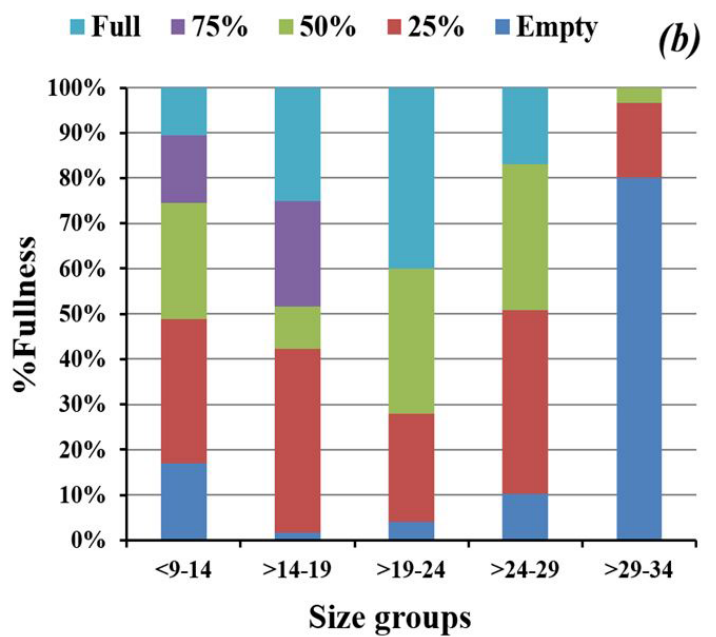

Figure 2. Fullness index of fish stomach in different seasons (a) and size groups (b) of R. rita sampled from Padma River.

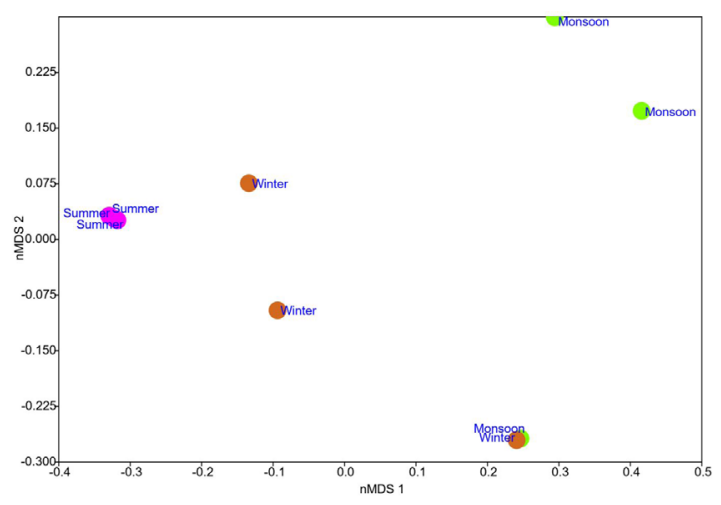

Figure 3. Seasonal variation in frequency of food items assessed by non-metric multidimensional scaling (nMDS) analysis in $R$. rita sampled from Padma River.

A significant difference was also observed among the seasons (ANOSIM, $R=0.638, P=0.013$ ) in terms of food items identified in the stomach of $R$. rita. Furthermore, the SIMPER analysis revealed $80.57 \%$ contribution of teleost (18.13\%), fish scale (18.06\%), mollusks (17.66\%), fish eggs (14.80\%) and plant materials (11.93\%) informing the seasonal variation of the food items in $R$. rita studied in Padma River. The dissimilarity between summer and monsoon season was $30.02 \%$, with fish scales (19.71\%) being the most prevalent food item making this difference. With the highest contribution of $27.84 \%$, mollusks created the dissimilarity of $17.08 \%$ between summer and winter food groups. Fish eggs, which were most abundant during the monsoon season, were noted to contribute (26.07\%) most in the dissimilarity (19.33\%) between monsoon and winter season's food items.

\subsection{Variations in the diet with fish size groups}

The broad-spectrum diet overlap was observed between the size class IV and V (Morisita's index $=1.20$ ), and the narrowest between I and IV (Morisita's index $=0.15$ ).
The size group III also showed higher dietary overlap between size groups IV and V (Morisita's index = 1.16 and 1.00 for III-IV and III-V, respectively). Fish with larger size groups preferred to have nearly similar food items that increased their diet overlap value. On the contrary, smaller body size, together with little mouth gaps, made the smaller size groups compatible with the only food items that were easy to capture, such as zooplankton and insects, which decreased dietary overlap between size classes I and IV. This overlap in food items between the more substantial size fish groups increased the niche breadth of these size groups. Therefore, Levin's niche breadth index was arranged in the order of $0.88>0.81>0.78>0.63>0.43$ for the size classes V, IV, III, II and I, respectively. Principle component analysis (PCA) explained $95.39 \%$ of the total variance among the stomach contents and fish size groups with principal component (PC) 1 variance equal to $87.84 \%$, while PC 2 variance as 7.55\%. The PCA manifested a close association among the more substantial size group of fish (III, IV, and V), which was mostly influenced by the abundance of food items such as fish scales, fish eggs, teleost, mollusks, and plant materials. On the other hand, smaller size groups (I and II) were found to show a higher correlation with the food items that were suitable for their ease of capturing such as Rotifera, Cladocera, and Copepoda (Figure 4). The hierarchical clustering of size groups based on the percentage frequency of each food item created three distinct clusters at the similarity level of $90 \%$. Clusters A and C individually represented the size groups I and II, respectively. In contrast, cluster B was a cumulative group of size classes III, IV, and V (Figure 5) that justified the output of PCA analysis.

\subsection{Morphometric relation with food items}

Measurements of different morphometric characters of R. rita collected from the Padma River are shown in Table 2. Total length (TL) and body weight (BW) of the investigated fish varied between 9-34 cm and 10-400 $\mathrm{g}$ with mean values of $20.53 \pm 6.90 \mathrm{~cm}$ and $125.94 \pm 102.07 \mathrm{~g}$, respectively. $R$. rita 


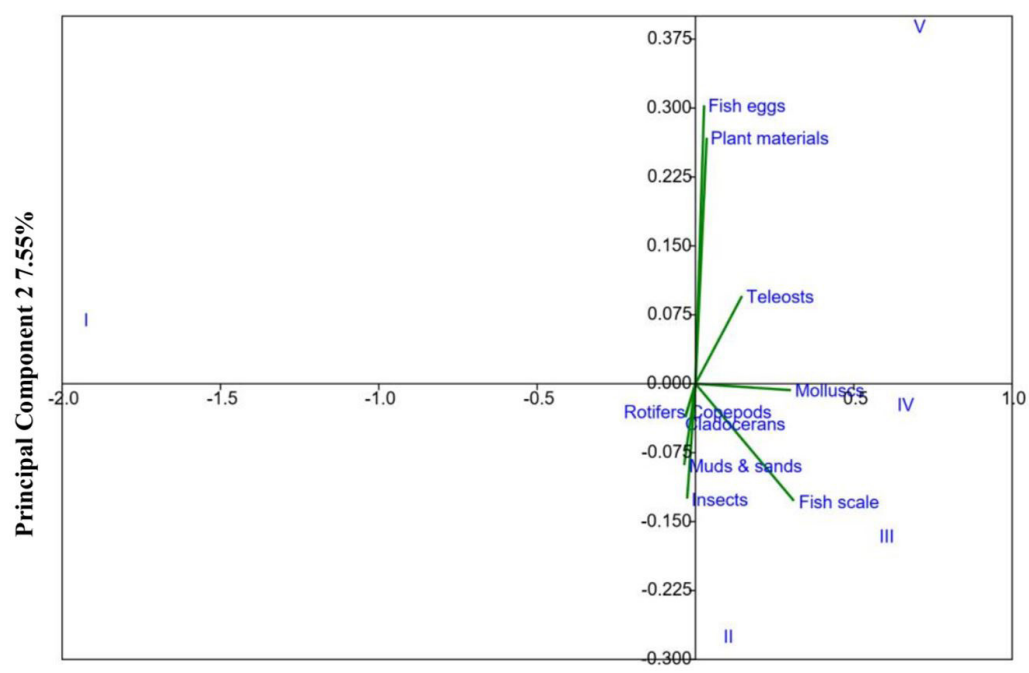

Principal Component $187.84 \%$

Figure 4. Principle component analysis (PCA) on fish size groups and food items in $R$. rita sampled from Padma River (Roman numbers indicated the different size group of fish, such as I = 9-14 cm, II = >14-19 cm, III = >19-24 cm, IV = >24-29 cm and V = >29-34 cm).

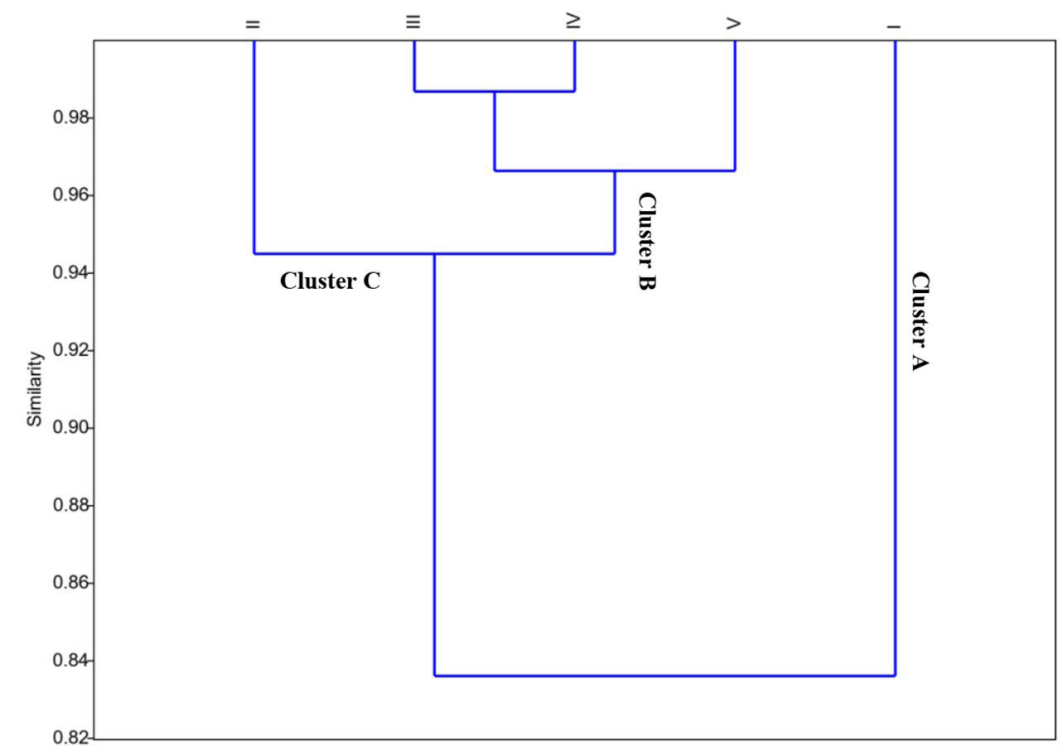

Figure 5. Links between the fish size groups based on cluster analysis in $R$. rita sampled from Padma River (Roman numbers indicated the different size group of fish, such as I = 9-14 cm, II = >14-19 cm, III = >19-24 cm, IV = >24-29 $\mathrm{cm}$ and V = >29-34 cm).

Table 2. Descriptive statistics of body morphometric and mouth dimensions in Rita rita from Padma river.

\begin{tabular}{lccc}
\hline Variables & Minimum & Maximum & Mean \pm SD \\
\hline TL & 9.00 & 34.00 & $20.53 \pm 6.90$ \\
BW & 10.00 & 400.00 & $125.94 \pm 102.07$ \\
HG & 1.00 & 1.60 & $1.21 \pm 0.11$ \\
VG & 1.00 & 4.00 & $2.67 \pm 0.76$ \\
MA & 1.00 & 4.46 & $2.59 \pm 0.90$ \\
\hline
\end{tabular}

$\mathrm{SD}=$ Standard deviation; $\mathrm{TL}=$ Total length; $\mathrm{BW}=$ Body weight $; \mathrm{HG}=$ horizontal mouth gape; $\mathrm{VG}$ = vertical mouth gape; $\mathrm{MA}=$ mouth area. displayed a horizontal mouth gape (HG) of $1.21 \pm 0.11 \mathrm{~cm}$ and vertical mouth gape $(\mathrm{VG})$ of $2.67 \pm 0.76 \mathrm{~cm}$. Mouth area (MA), which was calculated from HG and VG, varied from $1.00-4.46 \mathrm{~cm}$ and the mean value was $2.59 \pm 0.90 \mathrm{~cm}$. Table 3 shows the relation between body morphometric and mouth dimensions of $R$. rita. All the relationships were highly significant (ANOVA, $\mathrm{P}<0.01$ ) with $r^{2}$ value higher than 0.80 except for the relations of HG vs. TL, HG vs. VG, and HG vs. MA. Canonical correspondence analysis (CCA) demonstrated the relationship between the morphometric measurements and food items (Figure 6). In contrast, the first two axes of CCA explained $99.10 \%$ total data variability 


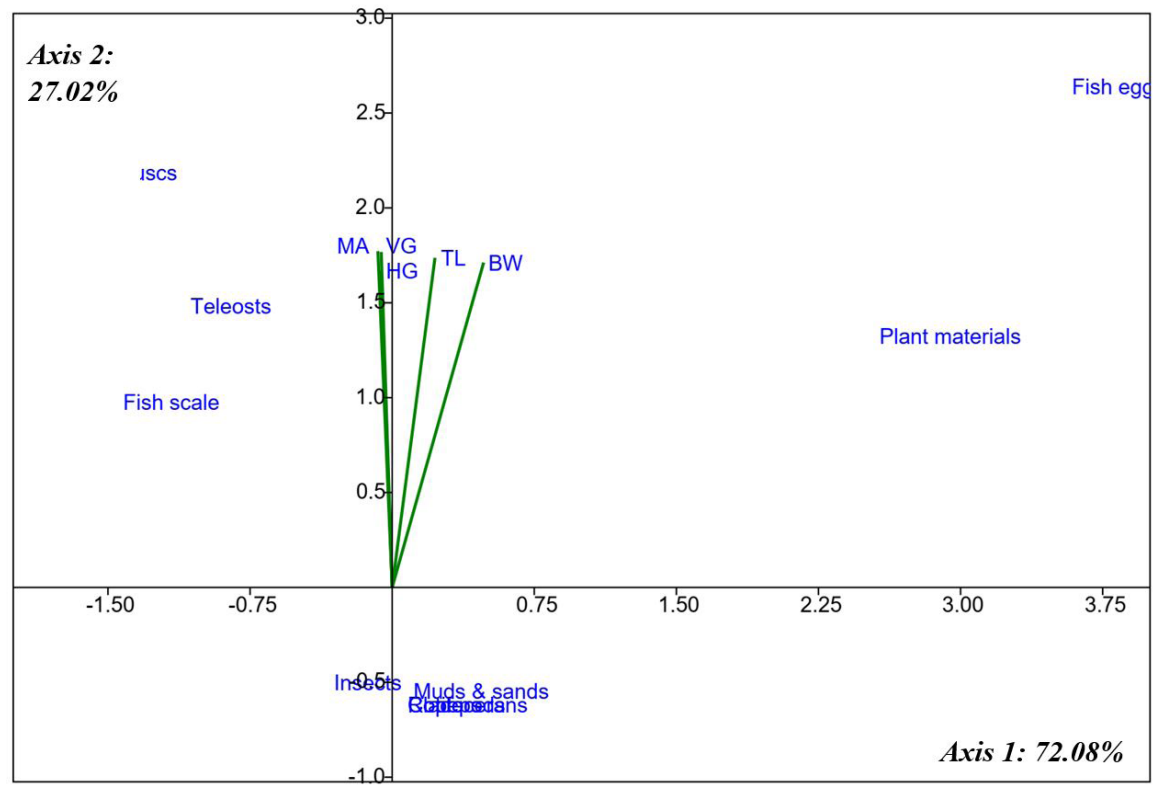

Figure 6. Canonical correspondence analysis of food items and morphometric measures of $R$. rita sampled from Padma river $(\mathrm{TL}=\mathrm{Total}$ length; $\mathrm{BW}=$ Body weight; $\mathrm{HG}=$ horizontal mouth gape; $\mathrm{VG}=$ vertical mouth gape; $\mathrm{MA}=$ mouth area)

Table 3. Relationship between body morphometric and mouth dimensions of $R$. rita from Padma river.

\begin{tabular}{|c|c|c|c|c|c|c|c|}
\hline \multirow{2}{*}{ Equations } & \multicolumn{7}{|c|}{ Regression parameters } \\
\hline & $\mathbf{a}$ & 95\% CL of a & SE (a) & b & 95\% CL of b & SE (b) & $\mathbf{r}^{2}$ \\
\hline $\mathrm{BW}=a \times \times^{\mathrm{b}}$ & 0.047 & $0.038-0.058$ & 0.015 & 2.540 & $2.470-2.609$ & 0.035 & 0.959 \\
\hline $\mathrm{HG}=a+\mathrm{L}$ & 0.391 & $0.326-0.456$ & 0.033 & 0.196 & $0.174-0.218$ & 0.011 & 0.585 \\
\hline $\mathrm{VG}=a+\mathrm{L}$ & 1.438 & $1.291-1.585$ & 0.075 & 0.801 & $0.752-0.851$ & 0.025 & 0.822 \\
\hline $\mathrm{MA}=a+\mathrm{L}$ & -070 & $-(226)--(114)$ & 0.079 & 0.997 & $0.945-1.050$ & 0.027 & 0.864 \\
\hline $\mathrm{HG}=a+\mathrm{G}$ & 0.007 & $0.609--(021)$ & 0.014 & 0.195 & $0.017-0.223$ & 0.014 & 0.452 \\
\hline $\mathrm{HG}=a+\mathrm{A}$ & 0.022 & $0.004-0.041$ & 0.009 & 0.189 & $0.170-0.208$ & 0.010 & 0.628 \\
\hline $\mathrm{VG}=a+\mathrm{A}$ & 0.219 & $0.201-0.238$ & 0.009 & 0.811 & $0.792-0.830$ & 0.010 & 0.969 \\
\hline
\end{tabular}

$\mathrm{BW}=$ Body weight; $\mathrm{HG}=$ horizontal mouth gape; $\mathrm{VG}=$ vertical mouth gape; $\mathrm{MA}=$ mouth area; $a$ is the intercept the slope; SE the standard error of mean; and $\mathrm{CL}$ is the confidence interval.

with the eigenvalues of 72.08 and $27.02 \%$ for axis 1 and 2 , respectively. However, the permutation test was significant for axis $2(\mathrm{P}=0.016)$. According to CCA analysis, the relation of food items such as fish scales, fish eggs, teleost, mollusks, and plant materials with the morphometric characters was highly positive, whereas copepods, cladocerans, rotifers, and insects were negatively influenced by the increased morphometric measures of $R$. rita.

\section{Discussion}

During the study period, the importance of food items of R. rita in Padma River was expressed with IRI\%. As IRI\% depends on the percentage of numerical, weighted, and the frequency of occurrence value, it is more trustworthy and applicable for revealing trends of data related to food items in the diet (Behzadi et al., 2018). We identified ten types of food items in the stomach of R. rita, and the present findings are similar to the results of Alam et al. (2016) in Ganges River and Mushahida-Al-Noor et al. (2013) in Padma River. Iqbal and Waseem (2008) also studied that the gut content of $R$. rita, which constituted of four food items identified as crustaceans, mollusks, shells, fish scales, and rotten vegetation/debris. Overall, the present study demonstrated that crustaceans (Copepods, Cladocerans, Rotifers, and insects) were the essential food items for R. rita in Padma River. Among the crustaceans, rotifers constituted a significant proportion according to the value of IRI\% index. Similar observations were made by Mushahida-Al-Noor et al. (2013), where they reported the dominance of crustaceans in the food items of $R$. rita from the same river. Apart from crustaceans, teleost, fish scales, and mollusks were the abundant food items of $R$. rita during the study period. Although quantitative variation in the IRI\% index of food items was observed, qualitative 
similarities among them justified the opportunistic feeding activity by $R$. rita in the Padma River. However, seasonal and size-related variations in food item's importance were observed during the study period, which was due to the environmental conditions and maturity stage of fish (Oribhabor and Ogbeibu, 2012; Yazicioglu et al., 2018).

IRI\% index values of teleost, fish scales and mollusks were higher during the summer season compared to monsoon and winter seasons. Moreover, the higher percentage of the full stomach was recorded during the summer season that indicated the higher abundance of food items available in the environment. Similar observations were also made by Jewel et al. (2019), where they reported the richness of food items during the summer season in Padma River. During monsoon season, the number of food items in the water became scarce due to the higher volume of water that diluted the concentrations of available food items (Atique and An, 2019; Atique et al., 2020b; Haque et al., 2020). Monsoon season was also the breading season of $R$. rita (Rahman and Mollah, 2014) in Padma river. Therefore, the number of fish with an empty stomach increased in this season. The effect of gonadal maturation in stomach fullness was also reported by Abbas (2010) in freshwater catfish Eutropiichthys vacha. However, the stomach content of fish during monsoon season was mostly occupied by fish eggs, and again the more abundant fish contributed most to consume this food item due to their higher abundance in the river. Monsoon also caused the flooding of the dried area of the river, where the farmers generally grow their crops during the dry season. Therefore, intentional or unintentional intake of plant materials made a significant contribution to the food items in $R$. rita during the monsoon season. Flooding also caused an increased amount of mud and sand particles in the stomach of fish during the study period (Abera, 2007; Worie and Getahun, 2015; Admassu et al., 2015). Winter was the season with moderate food items in the fish stomach; the contribution of crustaceans was higher than the other two seasons. Abundant food items in water reduced the number of fish with an empty stomach and increased different fullness index categories of fish. Abundant and poor food items in the environment of Padma River during summer and monsoon seasons respectively caused the least dietary overlap (Morisita's index $=0.66$ ) between these seasons. Moreover, diverse niche breadth (Levin's index $=0.76$ ) was also observed during the summer season and the narrowest during monsoon season (Levin's index $=0.58$ ). During the study period, the variation of food items in the stomach was significant among the seasons, and teleost (18.13\%), fish scale (18.06\%), mollusks (17.66\%), fish eggs (14.80\%) and plant materials (11.93\%) were the most contributory food items causing this variation.

The tendency to consume the crustaceans in all size groups of $R$. rita was higher. However, IRI\% was found to decrease with an increasing body size of fish. Preference of crustaceans by smaller fish groups was also reported by Tesfahun (2018) in African catfish (Clarias gariepinus), and by Haubrock et al. (2018) in channel catfish (Ictalurus punctatus). Moreover, the IRI\% index values of food items such as fish scales, teleost, and mollusks were found to increase with an increasing fish size that might be due to their stronger and bigger jaws helping them to crush the larger food items. On the other hand, absence or little amount of these food items in the smaller fish groups proved their inability to include them in their diet (Mushahida-Al-Noor et al., 2013) that could be linked with smaller mouth size. Therefore, dietary differences are indeed potentially linked to gapelimited predation (Johnson et al., 2008). In general, the contribution of only animal origin food items was significant in smaller size group fish. In contrast, the contribution of all sorts of food items, including plant materials, increased with the size of fish. This proved an ontogenetic dietary shift from narrow to a broader range of food items and also shifts in the feeding habit from carnivorous to omnivorous feeding nature (Alam et al., 2016). As evident from the present study, diet overlap was the narrowest between I and IV (Morisita's index $=0.15$ ) size groups of fish due to their dissimilarity in the preference for food items. On the other hand, fish with larger size groups preferred to have nearly similar food items that increased their diet overlap value and niche breadth diversity (0.88). Principle component analysis (PCA) and cluster analysis (CA) also showed a close association among the larger size group of fish (III, IV, and V), whereas PCA provided distribution of food items with their importance indicated by variables length and CA demonstrated the grouping of food items in different size groups of fish. During the study period, the percentage of fish with an empty stomach was higher $(80 \%)$ in the larger size group ( $>29-34 \mathrm{~cm}$ ) of fish indicated reduced feeding intensity during the peak spawning period. This phenomenon was also described by Usman et al. (2018) in Plotosus canius and Khan et al. (2011) in Mysteus nemurus.

During the study period, BW of $R$. rita sampled was within the range of $10-400 \mathrm{~g}$ that was quite diverse than the findings reported by Alam et al. (2016). Therefore, the inclusion of quite smaller and larger sized fish provided more precision in the present study. The growth rate of VG was higher compared to HG of $R$. rita that indicated its adaptation for different food and feeding guilds (Koundal et al., 2016). Greater VG compared with HG was also indicative of the column-omnivore/carnivore feeding habit of $R$. rita that is similar to the findings of Koundal et al. (2016) in Mastacembelus armatus. Analysis of regression between total length and body weight implied a high allometric coefficient, which demonstrated a faster weight gain than length. Changes in body structure could also have an impact on the feeding habit of fish. Mouth morphometric dimensions (HG, VG and MA) were found to have a significant correlation with explained variances higher than 50\%, except for the regression between HG $v s$ VG. As there are no previous studies on the relation between the different mouth size dimensions for the studied species, sufficient comparison could not be made. However, studies conducted by Nilsson and Brönmark (2000) and Magnhagen and Heibo (2001) showed that the relation between mouth dimensions and body length was linear and increased with the total BW in pike (Esox lucius) fish samples. Moreover, CCA analysis in the present study described a profoundly positive influence of mouth dimensions on fish scales, fish eggs, teleost, mollusks, and plant materials, while negative with the food items such as copepods, cladocerans, rotifer, and insects. 


\section{Conclusion}

This study presented the food and feeding preferences of $R$. rita during various seasons and fish size groups in Padma River, Bangladesh. The R. rita showed variations in feeding intensity both at seasonal and ontogenetic scales. Environmental food abundance was found to shape the feeding habit of this fish species in Padma River. The fish also showed a typical carnivore nature during the early stages of life, and that was shifted to an omnivorous feeding type with increasing body size. Crustaceans constituted the major food items in the smaller size groups and were accompanied by fish scales, teleost, mollusks, and plant materials in the larger size group of fish. The present findings on the feeding activity pattern of $R$. rita could contribute to the existing knowledge on sustainable management of this potentially exploited endangered fish species. Additionally, the results of this study could contribute to the development of appropriate feed formulation techniques in aquaculture of this species.

\section{Acknowledgements}

"The authors (SM, KAG) express their sincere appreciation to the Deanship of Scientific Research at the King Saud University for its funding of this research through the Research Group Project No. 1440-0138."

\section{References}

ABBAS, A., 2010. Food and feeding habits of freshwater catfish, Eutropiichthys vacha (Bleeker). Indian Journal of Scientific Research, vol. 1, no. 2, pp. 83-86.

ABERA, L., 2007. Reproduction, food, length weight relationship and condition factor of African catfish Clarias gariepinus (Burchell, 1822) in Lake Babogaya, Ethiopia. Addis Ababa: Addis Ababa University. M.Sc. Thesis in Zoological Sciences (Fisheries and Aquatic Sciences).

ADMASSU, D., ABERA, L. and TADESSE, Z., 2015. The food and feeding habits of the African catfish, Clarias gariepinus (Burchell), in Lake Babogaya, Ethiopia. Global Journal of Fisheries and Aquaculture, vol. 3, no. 4, pp. 211-220.

ALAM, A., JOSHI, K.D. and DAS, S.C., 2016. Feeding and reproductive behaviour of the river catfish Rita rita (Hamilton, 1822) in the river Ganga. The Indian Journal of Animal Sciences, vol. 86, no. 6, pp. 736-740.

ATIQUE, U. and AN, K.-G., 2018. Stream health evaluation using a combined approach of multi-metric chemical pollution and biological integrity models. Water, vol. 10, no. 5, pp.661. http:// dx.doi.org/10.3390/w10050661.

ATIQUE, U. and AN, K.-G., 2019. Reservoir water quality assessment based on chemical parameters and the chlorophyll dynamics in relation to nutrient regime. Polish Journal of Environmental Studies, vol. 28, no. 3, pp. 1043-1061. http://dx.doi.org/10.15244/ pjoes/85675.

ATIQUE, U. and AN, K.-G., 2020. Landscape heterogeneity impacts water chemistry, nutrient regime, organic matter and chlorophyll dynamics in agricultural reservoirs. Ecological Indicators, vol. 110, pp. 105813. http://dx.doi.org/10.1016/j.ecolind.2019.105813.

ATIQUE, U., IQBAL, S., KHAN, N., QAZI, B., JAVEED, A., ANJUM, K.M., HAIDER, M.S., KHAN, T.A., MAHMOOD, S. and SHERZADA, S., 2020a. Multivariate assessment of water chemistry and metals in a river impacted by tanning industry. Fresenius Environmental Bulletin, vol. 29, pp. 3013-3025.

ATIQUE, U., KWON, S. and AN, K.-G., 2020b. Linking weir imprints with riverine water chemistry, microhabitat alterations, fish assemblages, chlorophyll-nutrient dynamics, and ecological health assessments. Ecological Indicators, vol. 117, pp. 106652. http://dx.doi.org/10.1016/j.ecolind.2020.106652.

ATIQUE, U., LIM, B., YOON, J. and AN, K.-G., 2019. Biological health assessments of lotic waters by biotic integrity indices and their relations to water chemistry. Water, vol. 11, no. 3, pp. 436. http://dx.doi.org/10.3390/w11030436.

BAE, D.-Y., ATIQUE, U., YOON, J., LIM, B. and AN, K.-G., 2020. Ecological risk assessment of urban streams using fish biomarkers of DNA damages and physiological responses. Polish Journal of Environmental Studies, vol. 29, no. 2, pp. 1077-1086. http:// dx.doi.org/10.15244/pjoes/104660.

BATOOL, S.S., KHAN, N., ATIQUE, U., AZMAT, H., IQBAL, K.J., MUGHAL, D.H., AHMAD, M.S., BATOOL, S., MUNAWAR, S., DOGAR, S., NAWAZ, M. and AMJAD, S., 2018. Impact of azomite supplemented diets on the growth and body composition of catfish (Pangasius hypophthalmus). Pakistan Journal of Zoology, vol. 48, no. 4, pp. 1205-1208.

BEHZADI, S., KAMRANI, E., KAYMARAM, F. and RANJBAR, M.S., 2018. Trophic level, food preference and feeding ecology of Rachycentron canadum (Linnaeus, 1766), in Hormuzgan Province waters (northern Persian Gulf and Oman Sea). Iranian Journal of Fisheries Science, vol. 17, no. 1, pp. 179-193. http://dx.doi. org/10.22092/IJFS.2018.115608.

BLABER, S.J.M., 1997. Fish and fisheries of tropical estuaries. London: Chapman and Hall, 367 p. Fish and Fisheries Series, no. 22.

BRAGA, R.R., BORNATOWSKI, H. and VITULE, J.R.S., 2012. Feeding ecology of fishes: an overview of worldwide publications. Reviews in Fish Biology and Fisheries, vol. 22, no. 4, pp. 915-929. http://dx.doi.org/10.1007/s11160-012-9273-7.

CAMPOS, D.M.A.R., SILVA, A.F., SALES, N.S., OLIVEIRA, R.E.M.C.C. and PESSANHA, A.L.M., 2015. Trophic relationships among fish assemblages in a mudflat within Brazilian marine protected area. Brazilian Journal of Oceanography, vol. 63, no. 2, pp. 135-146. http://dx.doi.org/10.1590/S167987592015091306302.

CRUZ ESCALONA, V.H.C. and ABITIA CÁRDENAS, L.A.A., 2004. General characteristics of the diet of Trachinotus paitensis (Teleostei: Carangidae) from San Ignacio Lagoon, Baja California Sur, Mexico. Revista de Biología Tropical, vol. 52, no. 1, pp. 139-141. http://dx.doi.org/10.15517/rbt.v52i1.14762. PMid:17357410.

ERZINI, K., GONÇALVES, J.M.S., BENTES, L. and LINO, P.G., 1997. Fish mouth dimensions and size selectivity in a portuguese long-line fishery. Journal of Applied Ichthyology, vol. 13, no. 1, pp. 41-44. http://dx.doi.org/10.1111/j.1439-0426.1997. tb00097.x.

FAGBENRO, O.A., ADEDIRE, C.O., AYOTUNDE, E.O. and FAMINU, E.O., 2000. Heamatological profile, food composition and digestive enzymes assay in the gut of the African bony tongue fish, Heterotis (Clupisudis) niloticus (Cuvier 1829) (Osteoglossidae). Tropical Zoology, vol. 13, no. 1, pp. 1-9. http://dx.doi.org/10.10 80/03946975.2000.10531125.

FATEMA, K., OMAR, W.M.W. and ISA, M.M., 2013. Identification of food and feeding habits of Mullet Fish, Liza Subviridis (Valenciennes, 1836), Valamugil Buchanani (Bleeker, 1853) from Merbok Estuar. Journal of Life Sciences and Technologies, 
vol. 1, no. 1, pp. 47-50. http://dx.doi.org/10.12720/ jolst.1.1.47-50.

GALIB, S.M., RASHID, M.A., CHAKI, N., MOHSIN, A.B.M. and JOADDER, M.A.R., 2016. Seasonal variation and community structure of fishes in the Mahananda River with special reference to conservation issues. Journal of Fisheries, vol. 4, no. 1, pp. 325334. http://dx.doi.org/10.17017/jfish.v4i1.2016.139.

GONDAL, M.A., IQBAL, S., ATIQUE, U., SAHER, N.U., QURESHI, N.A., MAHBOOB, S., AL-GHANIM, K.A., AL-MISNED, F., 2020. Linking fish and crustacean taxonomic composition with seasonal contrasts in the soft-bottom intertidal zone. Brazilian Journal of Biology, vol. 6984, pp. 1-14. https://doi.org/10.1590/1519-6984.234129.

GUPTA, S., 2015. Rita rita (Hamilton, 1822), a threatened fish of Indian subcontinent. International Research Journal of Biological Sciences, vol. 4, no. 11, pp. 70-73.

HAMMERT, Q., HARPER, D.A.T. and RYAN, P.D., 2001 [viewed 23 April 2020]. Past paleontological statistical software package for education and data analysis. Palaeontologia Electronica [online], vol. 4, no. 1, pp. 1-9. Available from: http://palaeo-electronica. org/2001_1/past/issue1_01.htm

HAQUE, M.A., JEWEL, M.A.S., ATIQUE, U., PAUL, A.K., IQBAL, S., 2020. Seasonal and spatial variation of flagellate communities in a tropical river. Limnologica, vol. 85, pp. 125824. doi: 10.1016/j. limno.2020.125824.

HARA, J., ATIQUE, U. and AN, K.G., 2020. Multiyear links between water chemistry, algal chlorophyll, drought-flood regime, and nutrient enrichment in a morphologically complex reservoir. International Journal of Environmental Research and Public Health, vol. 17, no. 9, pp. 3139. http://dx.doi.org/10.3390/ ijerph17093139. PMid:32365942.

HAUBROCK, P.J., BALZANI, P., JOHOVIC, I., INGHILESI, A.F., NOCITA, A. and TRICARICO, E., 2018. The diet of the alien channel catfish Ictalurus punctatus in the River Arno (Central Italy). Aquatic Invasions, vol. 13, no. 4, pp. 575-585. http://dx.doi.org/10.3391/ ai.2018.13.4.14

HYSLOP, E.J., 1980. Stomach contents analysis-a review of methods and their application. Journal of Fish Biology, vol. 17, no. 4, pp. 411-429. http://dx.doi.org/10.1111/j.1095-8649.1980. tb02775.x.

INTERNATIONAL UNION FOR CONSERVATION OF NATURE - IUCN, 2010. Red list of Bangladesh. Dhaka, Bangladesh: Bangladesh Country Office, vol. 5, Freshwater fishes.

IQBAL, M.M., ABBAS, S., IQBAL, K.J., HAIDER, M.S., ASHRAF, S., MUHAMMAD, N. and KHAN, A.M., 2017a. Status of fish diversity of Islam Barrage, river Sutlej, Punjab, Pakistan. Journal of Wildlife and Ecology, vol. 1, no. 3, pp. 27-35.

IQBAL, S., ATIQUE, U., SHARIF MUGHAL, M., KHAN, N., SULTAN HAIDER, M., IQBAL, K.J. and AKMAL, M., 2017b. Effect of selenium incorporated in feed on the hematological profile of tilapia (Oreochromis niloticus). Journal of Aquaculture Research E'Development, vol. 8, no. 10, 1000513. http://dx.doi. org/10.4172/2155-9546.1000513.

IQBAL, Z. and WASEEM, M., 2008. Gut content of the freshwater catfish Rita rita (Ham.) from River Sutlej, District Kasur, Pakistan. Punjab University Journal of Zoology, vol. 23, no. 1-2, pp. 27-35.

IQBAL, S., ATIQUE, U., MAHBOOB, S., HAIDER, M.S., IQBAL, H.S., AL-GHANIM, K.A., AL-MISNED, F., AHMED, Z. and MUGHAL, M.S., 2020. Effect of supplemental selenium in fish feed boosts growth and gut enzyme activity in juvenile tilapia (Oreochromis niloticus). Journal of King Saud University - Science, vol. 32, no. 5, pp. 2610-2616. http://dx.doi.org/10.1016/j. jksus.2020.05.001.
ISLAM, M.A., ISLAM, M.J., BARMAN, S.K., MORSHED, F. and MARINE, S.S., 2015. Study on present status of fish biodiversity in wetlands of Sylhet District, Bangladesh. Agriculture, Forestry and Fisheries, vol. 4, no. 6, pp. 296-299. http://dx.doi.org/10.11648/j. aff.20150406.20.

JEWEL, M.A.S., ALI, S.M.W., HAQUE, M.A., AHMED, M.G.U., IQBAL, S., ATIQUE, U., PERVIN, M.E., PAUL, A.K., 2020. Growth and Economics of Silver Barb (Barbonymus gonionotus) in Ricefish-vegetable Integrated Culture System at Different Stocking Densities in a Rainfed Arid Zone. Egyptian Journal of Aquatic Biology and Fisheries, vol. 24, pp. 459 - 476.

JEWEL, M.A.S., HAQUE, M.A., FERDOUS, M.S., KHATUN, M.S., HASAN, J. and BHUYAIN, M.A.B., 2019. Food and feeding habit of Reba Carp Cirrhinus reba in the Padma River, Northwestern Bangladesh. Su Ürünleri Dergisi, vol. 14, no. 1, pp. 1-6.

JEWEL, M.A.S., HAQUE, M.A., KHATUN, R. and RAHMAN, M.S., 2018. A comparative study of fish assemblage and diversity indices in two different aquatic habitats in Bangladesh: Lakhandaha Wetland and Atari River. Jordan Journal of Biological Sciences, vol. 11, no. 4, pp. 427-434.

JOHNSON, B.M., MARTINEZ, P.J., HAWKINS, J.A. and BESTGEN, K.R., 2008. Ranking predatory threats by nonnative fishes in the Yampa River, Colorado, via bioenergetics modeling. North American Journal of Fisheries Management, vol. 28, no. 6, pp. 1941-1953. http://dx.doi.org/10.1577/M07-199.1.

KHAN, M.S., AMBAK, M.A. and MOHSIN, A.K.M., 2011. Food and feeding biology of a tropical freshwater catfish, Mystus nemurus Cuvier and Valenciennes with reference to its functional morphology. Indian Journal of Fisheries, vol. 35, pp. 78-84.

KHANOM, D.A., NESA, A., JEWEL, M.A.S., HAQUE, M.A., PAUL, A.K., IQBAL, S., ATIQUE, U. and ALAM, L., 2020. Muscular tissue bioaccumulation and health risk assessment of heavy metals in two edible fish species (Gudusia chapra and Eutropiichthys vacha) in Padma River, Bangladesh. Punjab University Journal of Zoology, vol. 35, no. 1, pp. 81-89. http://dx.doi.org/10.17582/ journal.pujz/2020.35.1.81.89.

KIM, J.-J., ATIQUE, U. and AN, K.-G., 2019. Long-term ecological health assessment of a restored urban stream based on chemical water quality, physical habitat conditions and biological integrity. Water, vol. 11, no. 1, pp. 114. http://dx.doi. org/10.3390/w11010114.

KIM, J.-Y., ATIQUE, U. and AN, K.-G., 2021. Relative Abundance and Invasion Dynamics of Alien Fish Species Linked to Chemical Conditions, Ecosystem Health, Native Fish Assesmblage, and Stream Order. Water, vol. 13, pp. 158. https://doi.org/https:// doi.org/10.3390/w13020158.

KOUNDAL, S., KOUNDAL, A., SHARMA, I. and DHANZE, R., 2016. Mouth morphometry and body lengths with respect to the feeding habits of Hill stream fishes from Western Himalaya H.P. (India). International Journal of Fisheries and Aquatic Studies., vol. 4, no. 3, pp. 346-356.

KREBS, C.J., 1999a. Ecological methodology. 2nd ed. Menlo Park, CA: Addison-Wesley Longman.

KREBS, C.J., 1999b [viewed 23 April 2020]. Ecological methodology v.5.1 software [online]. Vancouver: Department of Zoology, University of British Columbia. Available from: http://nhsbig. inhs.uiuc.edu/wes/krebs.html

MAGNHAGEN, C. and HEIBO, E., 2001. Gape size allometry in pike reflects variation between lakes in prey availability and relative body depth. Functional Ecology, vol. 15, no. 6, pp. 754-762. http:// dx.doi.org/10.1046/j.0269-8463.2001.00576.x.

MOHANTY, B.P., MITRA, T., BANERJEE, S., BHATTACHARJEE, S., MAHANTY, A., GANGULY, S., PUROHIT, G.K., KARUNAKARAN, D. 
and MOHANTY, S., 2015. Proteomic profiling of white muscle from freshwater catfish Rita rita. Fish Physiology and Biochemistry, vol. 41, no. 3, pp. 789-802. http://dx.doi.org/10.1007/s10695015-0046-9. PMid:25810140.

MOLLA, M.F.A., AMIN, M.R., SAROWAR, M.N. and MUHAMMADULLAH, M., 2008. Induced breeding of the riverine catfish Rita rita. Journal of the Bangladesh Agricultural University, vol. 6, no. 2, pp. 361-366. http://dx.doi.org/10.3329/jbau.v6i2.4835.

MOMI, M.M.A., ISLAM, M.S., FARHANA, T., IQBAL, S., PAUL, A.K., ATIQUE, U., 2021. How seasonal fish biodiversity is impacting local river fisheries and fishers socioeconomic condition: A case study in Bangladesh. Journal of Survey in Fisheries Sciences. vol. 7, pp. 79-103.

MOON, W.-K., ATIQUE, U. and AN, K.G., 2020. Ecological risk assessments and eco-toxicity analyses using chemical, biological, physiological responses, DNA damages and genelevel biomarkers in Zebrafish (Danio rerio) in an urban stream. Chemosphere, vol. 239, pp. 124754. http://dx.doi.org/10.1016/j. chemosphere.2019.124754. PMid:31726531.

MUHAMMAD, N., UMAIR, M., KHAN, A.M., YAQOOB, M., ASHRAF, S., HAIDER, M.S., CHATTHA, S.A., ANSARI, Z.S., YAQOOB, M. and IQBAL, K.J., 2019. Statistical analysis of freshwater fishes of head Khanki, Punjab, Pakistan. Journal of Wildlife and Ecology, vol. 3, pp. 1-9.

MUSHAHIDA-AL-NOOR, S., SAMAD, M.A. and BHUIYAN, N.I.M.A., 2013. Food and feeding habit of the critically endangered catfish Rita rita (Hamilton) from the Padda river in the north-western region of Bangladesh. International Journal of Advancements in Research and Technology., vol. 2, no. 1, pp. 155-166.

NILSSON, P.A. and BRÖNMARK, C., 2000. Prey vulnerability to a gape-size limited predator: behavioural and morphological impacts on Northern Pike Piscivory. Oikos, vol. 88, no. 3, pp. 539-546. http://dx.doi.org/10.1034/j.1600-0706.2000.880310.x.

ORIBHABOR, B.J. and OGBEIBU, A.E., 2012. The food and feeding habit of fish species assemblage in a Niger Delta Mangrove Creek, Nigeria. Su Ürünleri Dergisi, vol. 7, no. 2, pp. 134-149. http://dx.doi.org/10.3923/jfas.2012.134.149.

PALMEIRA, L.P. and MONTEIRO-NETO, C., 2010. Ecomorphology and food habits of teleost fishes Trachinotus carolinus (Teleostei: Carangidae) and Menticirrhus littoralis (Teleostei: Sciaenidae), inhabiting the surf zone off Niterói, Rio De Janeiro, Brazil. Brazilian Journal of Oceanography, vol. 58, no. spe4, pp. 1-9. http://dx.doi.org/10.1590/S1679-87592010000800002.

PARVEZ, I., ALAM, M.A., HASSAN, M.M., ARA, Y., HOSHAN, I. and KIBRIA, A.S.M., 2019. A checklist of fish species from three rivers in northwestern Bangladesh based on a seven-year survey. Journal of Threatened Taxa, vol. 11, no. 6, pp. 1378613794. http://dx.doi.org/10.11609/jott.4303.11.6.13786-13794.

RAHMAN, M.L. and MOLLAH, M.F.A., 2014. Determination of breeding season of endangered riverine catfish Rita rita (Hamilton, 1822) by studying ovarian development and Gonado-Somatic-Index.
Journal of the Bangladesh Agricultural University, vol. 11, no. 2, pp. 341-348. http://dx.doi.org/10.3329/jbau.v11i2.19938.

RAHMAN, M.M., HAQUE, S.M., ISLAM, M.A., PAUL, A.K., IQBAL, S., ATIQUE, U., WAHAB, A., EGNA, H. and BROWN, C., 2020. Assessment of mud crab fattening and culture practices in coastal Bangladesh: understanding the current technologies and development. Aquaculture, Aquarium, Conservation \& Legislation, vol. 13, pp. 582-596.

SAEED, F., IQBAL, K.J., ATIQUE, U., JAVID, A., KHAN, N., IQBAL, S., MAJEED, H., AZMAT, H., KHAN, B.Y.A., BABOO, I., SHAHID, M.T. and AFZAL, G., 2020. Toxic trace metals assessment in selected organs of edible fish species, sediment and water in Head Punjnad, Punjab, Pakistan. Punjab University Journal of Zoology, vol. 35, pp. 43-50.

SULTANA, A., SARKER, A.C., KUNDA, M. and MAZUMDER, S.K., 2017 [viewed 23 April 2020]. Present status and threats to fish diversity of wetlands of Chhatak, Bangladesh. International Journal of Fisheries and Aquatic Studies [online], vol. 5, no. 5, pp. 43-48. Available from: http://www.fisheriesjournal.com/ archives/2017/vol5issue5/PartA/5-3-66-975.pdf

TASLIMA, K. and MOLLAH, M.F.A., 2012. Induced breeding and larvae rearing of critically endangered riverine catfish Rita rita (Hamilton). Asian Fisheries Science, vol. 25, no. 1, pp. 85-96.

TESFAHUN, A., 2018. Feeding biology of the African catfish Clarias gariepinus (Burchell) in some of Ethiopian Lakes: a review. International Journal of Fauna and Biological Studies., vol. 5, no. 1, pp. 19-23.

UGWUMBA, A.A. and UGWUMBA, O.A., 2007. Food and feeding ecology of fishes in Nigeria. Ibadan: Jodetan Ventures, $70 \mathrm{p}$.

USMAN, B.I., AMIN, S.M.N., ARSHAD, A., KAMARUDIN, M.S. and HENA, M.K.A., 2018. Stomach contents of (Hamilton, 1822) in the coastal waters of Port Dickson, Peninsular Malaysia. Journal of Environmental Biology, vol. 39, no. 5(SI), pp. 907-912. http:// dx.doi.org/10.22438/jeb/39/5(SI)/18.

WORIE, W. and GETAHUN, A., 2015. The food and feeding ecology of Nile tilapia, O. niloticus, in Lake Hayq, Ethiopia. International Journal of Fisheries and Aquatic Studies, vol. 2, pp. 176-185.

YAZICIOGLU, O., POLAT, N. and YILMAZ, S., 2018. Feeding biology of pike, Esox lucius L., 1758 Inhabiting Lake Ladik, Turkey. Turkish Journal of Fisheries and Aquatic Sciences, vol. 18, no. 10, pp. 1215-1226. http://dx.doi.org/10.4194/13032712-v18_10_08.

ZACHARIA, P., 2004. Trophodynamics and Review of methods for Stomach content analysis of fishes. Kerala: Winter School \& Senior Scientist, Central Marine Fisheries Research Institute. Technical Notes.

ZAHORCSAK, P., SILVANO, R.A.M. and SAZIMA, I., 2000. Feeding biology of a guild of benthivorous fishes in a sandy shore on South-Eastern Brazilian Coast. Revista Brasileira de Biologia, vol. 60, no. 3, pp. 511-518. http://dx.doi.org/10.1590/S003471082000000300016 . PMid:11188877. 